\title{
6 \\ Voices and choices in reproductive rights: Scholarship and activism
}

Sylvia Estrada-Claudio

There has been a long struggle for reproductive health in the Philippines. In this chapter, I reflect on the process leading up to the passage of the Reproductive Health Bill in the Philippines in December 2012. Although there is much to be dissatisfied with in the implementation of the Bill, the process leading up to its passage in 2012 is instructive. This prompts reflection on the role of academics in promoting social change, the possibility of coalitions between academics and activists, and the importance of transnational solidarity, even in campaigns focused largely in a particular national context. Opposition to the Bill, on the part of the Catholic Church of the Philippines, also drew on international connections and communication between conservative lobby groups. Furthermore, policies on reproductive health and human rights issues have international repercussions where they weaken the efficacy of international agreements on such issues.

On 13 December 2012, the House of Representatives (HOR) of the Republic of the Philippines passed, on second reading, House Bill 4244, ${ }^{1}$ better known as the RH (Reproductive Health) Bill. The passage in the HOR on second reading gave

1 The full title is An Act Providing for a Comprehensive Policy on Responsible Parenthood, Reproductive Health, and Population and Development, and for Other Purposes. Hereinafter, 'Reproductive Health Bill' or 'RH Bill'. 
President Benigno Simeon Aquino III the necessary political capital to certify the Bill as urgent. This paved the way for the Philippines Senate to set aside the mandated three-day waiting period between second and third readings of its own version, An Act Providing for a National Policy on Reproductive Health and Population and Development, and vote the Bill into law on 17 December 2012. On that same day, the HOR voted to pass the Reproductive Health Bill into law on third reading. President Aquino subsequently signed the consolidated version of both houses of the Philippine Congress on 21 December 2012 into law as the The Responsible Parenthood and Reproductive Health Act of 2012 (hereinafter, the RH law). Subsequently, on 16 March 2013, the RH law's implementing rules and regulations were also signed, in a working-class community in Manila.

The certification of the RH Bill as urgent was necessary because the last weeks of 2012 were also the last few weeks before the adjournment of the Fifteenth Congress. After 12 years, ${ }^{2}$ beginning with the Twelfth Congress, the Philippines finally had a law that mandated the provision of reproductive health services ${ }^{3}$ that is, until 19 March 2013, when, in response to petitions alleging the law to be unconstitutional, the Supreme Court issued a status quo ante order (SQAO) stopping implementation for 120 days (Republic of the Philippines, Supreme Court En Banc Notice, 19 March 2013). On 8 April 2014, the Supreme Court ruled that the law was 'not unconstitutional' but struck down eight provisions partially or in full (Bernal 2014). Advocates of the Bill (now referred to as the law) believe that the provisions struck down do not prevent the implementation of an effective reproductive health program by the Philippine government.

Interest in the struggle for the passage of the law has long extended beyond Philippine society. ${ }^{4}$ The long struggle of reproductive health advocates has touched on many themes relevant to this volume: struggles and solidarities across national borders, and the roles of different academies and social science traditions.

The main opposition to the law comes from the Catholic Bishops' Conference in the Philippines (CBCP). The CBCP opposes what it refers to as 'DEATH' legislation, which, according to them, is an acronym for 'divorce, euthanasia,

\footnotetext{
2 Other actors would say that the count actually began in the Eleventh Congress and therefore took 16 years. The difference in dating is in itself indicative of the various views of those who advocated for the law. Advocates who were uncomfortable with what they perceived as a mix of both health and demographic targets in the bills filed in the Eleventh Congress begin their 'count' from the Bill filed during the Twelfth Congress.

3 The law does not change other laws that make abortion illegal under all circumstances. It does, however, mandate the prevention and management of abortion complications and the humane care of women who seek care after a miscarriage or abortion.

4 See, for example, Rina Jimenez David's comments at the 'Women Deliver' international conference on reproductive health, which was held after the issuance of the Supreme Court's status quo ante order. Despite this, Jimenez David reports, 'Women Deliver co-organizer Dr. Raj Karim said it was time "to celebrate" in the Philippines, the passage of the RH Law' (Jiminez David 2013).
} 
abortion, total reproductive contraception and homosexuality' (GMA News Online 2008). The Philippine situation reflects closely the social policy positions of the Roman Catholic Church on sexual reproductive rights (CBCP 2000). Thus, the Philippines is the last country in the world that does not allow divorce (after Malta passed a divorce law in 2011) (BBC 2011). It is part of a small minority of countries that penalise abortion under all circumstances, prompting the UN Human Rights Council (UNHRC 2012: 4), in its concluding remarks in its last review of Philippine commitments, to recommend that the government ensure that exceptions be made to protect the life of the mother and in cases of incest and rape. The Philippines is also part of a diminishing number of countries that do not have an explicit policy on non-discrimination against lesbian, gay, bisexual and transgender (LGBT) peoples - a matter also noted by the UNHRC (2012: 3).

This position is not merely that of the Philippine clergy. The CBCP repeatedly cites its allegiance to Catholic theology as espoused by the curia. The well-known opposition of the Vatican to divorce, euthanasia, abortion, contraception and homosexuality has been a mark of its contemporary theology (Cochrane 2004).

The Philippines is the last bastion of Catholic conservatism in Asia. Through the centuries, since the time of Spanish colonisation, when the Philippines was run like a Catholic theocracy, politicians have been afraid to alienate the church. An oft-cited saying is that 'Philippine politics is addition'. This means that politicians will always welcome the support of any large, organised group like the Catholic church. The previous administration, of Gloria Macapagal Arroyo, is illustrative. During the regime of her successor, Arroyo has been in and out of jail or house arrest because of several court cases against her, relating to election sabotage and plunder (Salaverria 2012). Her presidency survived repeated corruption scandals. The most serious threat, however, was a crisis in which there was credible evidence that she had cheated in order to win the presidency. In the cases of former presidents Ferdinand Marcos (1979-89) and Joseph Estrada (1988-2001), the church had been a factor in their ousting. In the case of Arroyo, the church has proven to be her saviour (Rufo 2013: 123-27). During her administration, Arroyo and most of her allies in the legislature ensured the defeat of reproductive health bills. She has also consistently de-emphasised and defunded reproductive health programs in the country (Estrada-Claudio 2010).

The Philippines has become increasingly important to the Vatican because Catholicism is waning in Europe and in areas where the church had influence as a result of colonialism, such as Latin America. Hagopian (2009: 2) cites several challenges to the Catholic church's power in Latin America, including centre-left and leftist politicians who are 'responsive to new demands for social and family policy reform and reproductive rights that run counter to the church's teachings'. Hagopian further cites several examples of the increasingly 
libertarian laws around homosexuality, divorce and abortion in Latin America (2009: 2). Thus, the outcome of reproductive health legislation in the Philippines is significant to the Vatican. It is also, of course, significant to the individuals, institutions and movements who seek to strengthen women's rights.

The connivance of the Philippine government with the Vatican plays out in the international arena as well, where the Philippines has often served as a Vatican ally in struggles in forums such as the UN International Conference on Population and Development (UNICPD) (Danguilan 1997). Women's rights activists working in the United Nations have waged decades-long battles with the Vatican because of its fundamentalist positions. Indeed, in 2006, UN secretary-general Kofi Anan stated that the "politicization of culture in the form of religious "fundamentalisms" in diverse geographic and religious contexts has become a serious challenge to efforts to secure women's human rights' (UN 2006: 30).

In the case of Catholic fundamentalism or extremism, therefore, I would argue that the Philippines is on the front line. The struggle for reproductive health legislation is a local struggle that has global repercussions for all societies seeking to establish an effective human rights regime in the international arena. The international arena has permissive or restrictive effects for many national contexts, even for those in the developed world.

The logistical and ideological support for the anti-RH position from forces outside the Philippines is another example of the transnational nature of certain local struggles. The websites of the organisations which petitioned the Supreme Court to declare the RH law unconstitutional show that they either are affiliates of international organisations or have links to organisations in other countriesnotably, the United States. ${ }^{5}$

The arguments used by anti-RH advocates in the Philippines not only echo the Vatican line that contraception is sinful, they also echo quasi-scientific arguments that can be found among US-based fundamentalist groups. Those who petitioned the Supreme Court of the Philippines to invalidate the $\mathrm{RH}$ law argue that it violates a constitutional provision that 'equally protects the rights of the mother and the unborn from the moment of conception'. They argue that some hormonal preparations and the intrauterine device

5 The Supreme Court petitioner, Alliance for the Family Foundation Philippines, is linked to the American Life League. On the American Life League, see Alliance for the Family Foundation Philippines (n.d.). Another petitioner, Pro-Life Philippines (2015), notes in its history that it began with its founder Sr Pilar Verzosa meeting the founder of Human Life International (HLI). HLI is a US-based organisation that lists Dr Ligaya Acosta as its Regional Director for Asia and Oceania. See Human Life International (n.d.). Dr Acosta is a Filipina who is one of the main spokespeople of the anti-RH movement. The website of HLI (www.hli.org) also has several features on the RH struggle in the Philippines. See Footnote 7 for the link to the Supreme Court en banc decision to consolidate petitions. Petitioners are listed on the first page of that document. 
(IUD) work to prevent the implantation of the fertilised ovum, and that these contraceptives therefore cause abortion. This is the very same argument we see coming from the American Association of ProLife Obstetricians and Gynecologists (Colliton n.d.). It would seem that the Vatican itself knows the importance of the link between local struggles and the international arena, as it has worked with other fundamentalist governments and forces to turn back human rights work at the United Nations. ${ }^{6}$

Another theme is the relationship between the academy, society and nationbuilding. Many of the academics who became involved in the campaign for the $\mathrm{RH}$ Bill considered involvement in the effort part of their scholarship. This kind of engagement continues a tradition of academic involvement in nationbuilding and in postcolonial struggles. This type of engagement is also nuanced by the particular history of the academic institution and its own engagement with colonialism, anticolonial struggles and nation-building, as I will discuss below. To do so, it is necessary to give a short description of the universities that became players in the national debate on the RH law. I shall begin by describing two universities that, as institutions, are polar opposites: the University of the Philippines (UP) and the University of Santo Tomas (UST).

At the time of its establishment in 1908, UP was the showcase for the libertarian and Enlightenment ideals of the American occupiers. The leading academic institution at that time was the Pontifical UST (de Dios 2008: 1). Established in 1611 , the UST became a symbol of theocratic abuses in education under Spanish colonialism. This is epitomised in the description of a physics class at the UST in the novel El Filibusterismo (The Filibuster) by the Philippines' national hero, José Rizal (1861-96). The UST had resisted a decree in 1868 by the Spanish revolutionary government to secularise and be renamed the University of the Philippines. That resistance lasted until the restoration of the monarchy, making the decree moot (Abinales and Amoroso 2005: 93). UST was bestowed the title of 'Pontifical University' in 1902 and 'The Catholic University of the Philippines' in 1947 (UST n.d.). Thus, UP and UST have been perceived by historians and many present-day members of these institutions as contrapuntal.

6 It must be noted that fundamentalism and intolerance are not confined to Roman Catholicism but are seen in all religions. Thus, in the United Nations, alliances are formed between conservatives from various religious groups. Such alliances caught the world's attention in 1994 during the UN International Conference on Population and Development in Cairo, as noted by Freedman (1996). Ten years later, in November 2004, Catholic, Muslim and US-based Christian fundamentalists met in Doha to discuss a united opposition to feminist interventions in the United Nations. Designated Muslim and Christian groups and individuals who organised the first meeting have since cooperated on joint actions, which have been particularly troubling in the United Nations, where the alliance has worked through the governmental delegations of several Arab countries. For example, a week after the Doha conference, the Government of Qatar put forward a conservative resolution on the family to the UN General Assembly, which was approved without a vote. This dismayed European countries and several others (Whitaker 2005). 
While both institutions, especially the secular and rambunctious UP, had both pro-RH and anti-RH adherents, the UP, through various university council resolutions, college positions and individual statements by its faculty and staff, had been a bastion of support for the RH Bill. UST, on the other hand, had served as a bastion of support for the anti-RH position.

The UP, through its various experts, had also served as technical support for the authors of the Bill in both chambers of the Philippine Congress. The technical support that the UP contributed to the RH struggle involved demographers, economists, development specialists, psychologists and health experts, to name a few. Demographers from the UP Population Institute, for example, provided the research and analysis that allowed a 'good enough' estimate of the country's maternal mortality rates. ${ }^{7}$ These high rates were then cited by health experts to underscore the need for access to contraceptives and to trained personnel and health facilities - key measures mandated in the law.

Two points need to be made here: first, scholars engaged in national events find that their scholarship, disciplinary interests and explorations are guided by what they feel their people need in order to live in dignity. Second, such engagement, however, is not merely one that extracts ideas such as research agendas from social movements. Rather, it gives back to these social movements. For it to be truly helpful, it requires the full application of scholarly discipline and rigour because the statements that were made during the course of the national debates were subject to the strongest contestation and scrutiny. In this sense, the UP faculty who supported the passage of the law were fulfilling UP's role as the secular and scientific voice for the nation.

The UST, on the other hand, consistent with its character as a Catholic university, firmly and officially opposed the passage of the RH law. Many of its faculty members would confront their pro-RH counterparts (many from UP) in debates, forums, roundtables and the like. Typically, while UP professors stuck to mainly scientific arguments, UST faculty would often refer to Catholic doctrine.

The academic fisticuffs between the UP and UST would eventually turn into a barroom brawl. In 2008, 14 professors from the Jesuit-run Ateneo de Manila University called for the immediate passage of the $\mathrm{RH}$ Bill. ${ }^{8}$ The professors stated clearly that the call was made in their capacity as individuals and was not that of the Ateneo. Nevertheless, the statement could not but carry the institutional cachet of the Ateneo. More importantly, however, the Ateneo

7 See, for example, the report by the Guttmacher Institute (2009). The report is co-authored by the UP Population Institute and Likhaan, a non-governmental organisation (NGO). The report itself illustrates the nature of the RH struggle in which an international and US-based private entity (Guttmacher) worked with an academic institution (UP) and an NGO.

8 See the position paper on the RH Bill by Individual Faculty of the Ateneo de Manila University (2008). 
professors challenged the hegemony of the anti-RH position within Catholic doctrine and argumentation. Citing the church's own teachings, they stated that Catholics could support the RH Bill in good conscience.

Voices against the $\mathrm{RH}$ Bill also came from within UP, with some professors ${ }^{9}$ circulating a position paper questioning certain demographic premises of the Bill and what these professors claimed were mistaken notions about population and the environment espoused in the Bill. Typical of UP, however, the position paper posed secular arguments rather than scientific ones.

The differences among the UP professors did not generate as much heat as the differences between the faculties of the Catholic universities of UST and Ateneo. While it is difficult to speculate on the reasons, it is typical and expected of the secular UP to contain divergent voices. The pro-RH position, representing as it does the position of mainstream scientific institutions such as the World Health Organization (WHO), had perhaps established a comfortable hegemony in UP. The Ateneo position, however, disrupted the hegemonic position of the anti-RH stance in the Catholic schools.

Anyone who is familiar with church history would not be surprised that a Jesuit-run institution would play such a role. In the Philippines, too, José Rizal was said to have remarked as he walked by the Ateneo on his way to his execution: 'All that the Jesuits taught me was good and virtuous' (National Historical Commission of the Philippines n.d.). This contrasts with his caustic portrayal of the UST physics classroom in The Filibuster.

The academic intramural debates over the $\mathrm{RH}$ Bill intensified in the final years of the campaign to pass the Bill into law. In March 2011, more than 200 professors from UP and Ateneo released a joint statement supporting the RH Bill. ${ }^{10}$ By this point, the original 14 professors who had signed the 2010 statement had increased their ranks several-fold. In August 2012, 192 professors from the Ateneo released yet another statement in support of the Bill. This produced the strongest backlash against these professors yet, with anti-RH forces, including

9 One cannot ascertain the number. As an advocate, I scrutinised the initial paper posted on the Internet, but it is no longer available. I could not verify the identities of most of the signatories. Many were clearly not UP faculty and some seemed to be alumni. I subsequently met two UP professors at a televised debate who claimed to be members of the group and responsible for the statement. They refused to state the number of faculty backing their statement. The only available source for this effort that I could find is a Facebook page with the name 'UP Students, Faculty and Alumni Against the RH Bill'. One clear arena for this struggle is new social media, but this is beyond the scope of this essay. There is also a Facebook page, 'Ateneans for $\mathrm{RH}^{\prime}$.

10 The number would have been higher if the Ateneo professors had not urged the release of the statement in March 2011. Many more from the UP had wanted to sign but the institutional context of our colleagues in Ateneo was such that we deemed it wise not to prolong the process of gathering signatures. 
some Catholic bishops, calling for their resignation or dismissal (Alave 2012). This also prompted the Ateneo leadership to officially state (yet again) that they supported the official position of the CBCP in opposing the RH Bill.

The following month, September 2012, 45 faculty and staff of De La Salle University (DLSU), a Catholic university founded in 1911 by the Brothers of the Christian Schools (DLSU n.d.), issued a statement of support for the RH Bill. This produced a similar backlash, with calls for their resignation or dismissal. In this case, too, the leadership of De La Salle had to issue a statement of clarification about the university's official position. ${ }^{11}$

An editorial in the Varsitarian, the student paper of UST, in October 2012 castigated the pro-RH professors for their refusal to obey official Catholic precepts (Varsitarian 2012). The editorial also accused the professors of not telling the truth about contraceptives. This caused a controversy in itself because the editorial was deemed by many to have overstepped the bounds of reasoned discussion, degenerating into name calling. The editorial was the only public indication of 'cracks' in the anti-RH position of UST (Suller 2012). ${ }^{12}$ The furore over the editorial eventually caused UST to dissociate itself from the editorial (Rappler 2012)..$^{13}$

In October 2012, a day after the release of the UST editorial, UP's Institute for Human Rights and the Center for Women's Studies hosted professors from Ateneo and DLSU in a forum. While the professors who served as speakers were some of the leading voices for the RH struggle, the topic of the forum was not the RH Bill. It was about the threats to academic freedom posed by those calling for the investigation of the professors of DLSU and Ateneo who had supported the Bill.

The threat to academic freedom from conservative religious movements is not merely a threat to educational institutions; yet academia is most vulnerable to fundamentalist movements because free thought is a necessary condition

11 In wonderfully nuanced statements, both DLSU and Ateneo nonetheless upheld the value of the differing voices of their faculty despite reiterating the church's position on the RH Bill.

12 The article cites one tweet from a UST student, @mashi_carigms: 'To every person who found the Varsitarian article derogatory \& offensive, as a Thomasian, I apologize for the blatant display of disrespect.' The article also reports the editorial of the Ateneo student paper, the Guidon, reacting to the UST editorial. The reaction echoes two tropes: the first being the claim to scientific authority by pro-RH advocates, and the second, an echo of Rizal's condemnation of the church's educational approach. The article quotes the Guidon as saying, 'Time and again, statistics have been disregarded and research has been misrepresented — not to mention plagiarized - in the effort to fight the bill. Ignorant and condemnatory statements have been made, invoking a rigid kind of Catholic theologizing completely out of touch with temporal realities.' The article goes on to report that ' $[\mathrm{t}]$ he Guidon editorial said it was unsettling how some members of the Catholic Bishops' Conference of the Philippines "seem to believe that universities are merely channels of indoctrination rather than institutions that foster intelligent discourse"'.

13 When the UST 'dissociated itself' from the statement, it also adverted to more secular values, saying that the Varsitarian was an independent student publication. 
for real scholarship. The strengthening of secular values through the defence of academic freedom as a means to counteract these threats is important. Additionally, in the course of the struggle for the RH Law in the Philippines, activist scholars in and out of academia have become increasingly convinced of the value of secularism in defence of sexual and reproductive rights.

Indeed, among the most important voices in the later part of the RH struggle were those of organisations whose main concern is secularism. These provided a counterpoint to the CBCP's attempt to make its religious stance appear to express the morality of the Philippine majority. This is exemplified by the organisation Filipino Freethinkers, which held the first 'excommunication party' on 26 November 2010. In the light of the CBCP's threat to excommunicate President Aquino for his support of the RH Bill, the party celebrated with the theme 'if supporting the RH Bill means excommunication, excommunicate me' (Filipino Freethinkers 2012). ${ }^{14}$

In the light of the resurgence of fundamentalisms, as noted by Anan (UN 2006), the Philippine case may present scholarship practices and traditions of value to cross-cutting transnational issues related to social development. Wezel (2006) argues that secularist values are important to social development. Using survey data from the World Values Survey, Wezel notes that, despite wide variations in people's orientations, these can be reduced to just two basic dimensions: weak versus strong secular-rational values and weak versus strong self-expression values. Secular-rational values include less emphasis on religion and national pride, more emphasis on independent thinking rather than respect for authorities, and the acceptance of divorce (as a marker for less emphasis on 'familism'). Self-expression values include liberty aspirations (that is, the enjoyment of civil and political rights), the acceptance of homosexuality (as a marker of tolerance of non-conformity), a strong sense of self-direction, participation in petition signing (used as a marker of the public expression of sentiments) and the ability to trust others. Wezel argues that where self-expression and secular-rational values are strong, there is a move towards choice. When the two dimensions are weak, there is a move towards constraint. Wezel concludes that moving from constraint to choice is necessary to human development because it makes people mentally free and allows them to develop their potential. Wezel also notes that at a social level, the move towards choice generates potential for democratic

14 As my position is important to one of the themes of this paper, I will add that I am a senior adviser of this young (in terms of membership and number of years of establishment) organisation. Red Tani, one of the founders of the organisation, has noted in several public talks as well as personal communications to me that they were not focused on the RH Bill until I spoke at the first Filipino Freethinker Forum on secularism and reproductive health on 2 March 2009. That talk is available on YouTube (www.youtube.com/ watch?v=BAyCZJYc0KO. Consulted 23 September 2013). 
reform. Wezel's data also chart countries along the two dimensions, revealing a trend towards choice and democracy in countries that achieve higher levels of economic well-being.

It is this inextricable link between the work of the scholar and the society in which he or she is embedded that is also illustrated by the struggle to pass the RH law. When not toiling in academia, I work with a non-governmental organisation (NGO) called Likhaan (Likhaan n.d.). Our core work has been to provide reproductive health services for women in poor urban communities using principles of participation and organisation. We have been at this work for almost two decades.

Likhaan decided to embark on legislative advocacy because we saw massive violations of women's rights. This has included bans on all forms of modern contraceptives in various local government units. The most notorious of these is a ban in the capital city of Manila imposed by its former mayor from 1998 to 2007 (Demeterio-Melgar et al. 2007). Likhaan has also documented other violations, including the denial of emergency obstetric care and post-abortion care to women. The RH law would, among other things, be an important step towards addressing the unacceptably high maternal mortality rate in the country. Similarly, HIV/AIDS activists see the law as part of a set of measures that would address our still-rising incidence of new infections (Department of Health-National Epidemiology Center 2012).

When we first filed proposed legislation on reproductive health more than a decade ago, it did not pass out of the congressional committee on healthone of the earliest of numerous steps towards passage into law. By the time the Bill was passed by both houses of the Philippines Congress, survey after survey had shown large majorities of our people knew of the provisions of the Bill and supported its passage. That support spans all socioeconomic classes (Social Weather Stations 2011). ${ }^{15}$ On the eve of the Supreme Court decision on the constitutionality of the Bill, Social Weather Stations (2014) released the results of a survey showing that 77 per cent of respondents agreed that 'the RH Law follows what the Constitution should stand for, so it is only proper for the Supreme Court to allow it'. ${ }^{16}$

15 Other notable findings are that 68 per cent say government should fund all means of family planning, whether artificial or natural. A plurality, 46 per cent, disagree that youth would be promiscuous if family planning were included in sexuality education. These statements were the most controversial aspects of the law because the $\mathrm{CBCP}$ and other anti-RH religious groups objected particularly to these provisions.

16 It is interesting that the level of support for contraceptive provision - the heart of the anti-RH argument that the law was unconstitutional — had increased from the 2011 survey. At this point, 84 per cent agreed that the government should provide free contraception. 
The importance of this support by the general public cannot be overemphasised. I am not aware of any piece of social legislation in recent Philippine history that has been so thoroughly discussed. It is a testament to the capacity of social movements and allies in other social institutions (media, the academy, certain government agencies) to undertake mass education leading to attitudinal change. Such a phenomenon must surely be of interest to many in the social sciences, including in my own areas of development studies, women's studies and social psychology. Regardless of whether the RH law will be fully implemented (legality being only one step towards full access), it will be interesting to track whether the general public, made aware of its reproductive health rights by the legislative struggle, will demand services from government. Certainly, the Department of Health and related agencies (for example, the Philippine Population Commission) have long registered support for the $\mathrm{RH}$ Bill-a change in attitude attributable in part to the advocacy for and passage of the law. ${ }^{17}$

Peculiar to my position as an academic at UP, I cannot but hark back to the university's mandate as stated in its charter: one of UP's functions is to 'lead as a public service university by providing various forms of community, public and volunteer service as well as scholarly and technical assistance to government, the private sector and civil society while maintaining its standards of excellence' (An Act to Strengthen The University of the Philippines as the National University, 2008).

As the reader may have guessed, UP's institutional context made it relatively easy for its faculty and staff to advocate for the RH Bill, including undertaking research on the matter. This does not, however, exempt those advocates from having to pay the price of this kind of engaged academic scholarship. In this chapter, I have presented an example of academic engagement that, although by no means the only formula for knowledge generation, is validated by its genuine effect on people's lives and dignity. Yet much of the work has not led to the type of knowledge products and activities given weight by recruitment, tenure and promotions systems (Commission on Community Engaged Scholarship in the

17 Dr Esperanza Cabral, for example, the predecessor of the current Department of Health (DOH) secretary, broke ranks with her boss, President Arroyo, in a series of public pronouncements backing both the RH Bill and the principles of reproductive health. On her becoming DOH secretary, a newspaper article stated: 'It will be recalled that Cabral stated her support for a national modern family planning program when she was Department of Social Welfare and Development secretary, going against the Malacañang line of backing only the Catholic Church-approved natural family planning as a national program. She said that there are many members of the Arroyo Cabinet who support the RH bill, but it was she who, by chance, opened up to members of the media. Cabral's predecessor in the Department of Health, Francisco Duque III, strictly toed the Malacañang line during his tenure' (Llaguno 2010). Malacañang is the official residence of the Philippine president and is often used as a synonym for the Office of the Philippine President. 
Health Professions 2005). ${ }^{18}$ While some knowledge products such as research were necessary for the advocacy, much of the work has been technical support to lawmakers, public statements, primers, newspaper articles, fact sheets, lobbying and organising - activities that would not be classified as scientific publications or as prestigious teaching activities. Indeed, the 'knowledge product' that I would be most proud of in this context is the RH Bill itself. Unfortunately, I cannot claim single, joint or main authorship of this document. Anecdotally, I might add that a number of my colleagues tend to scoff at the various international university ranking systems precisely because ranking criteria do not take into account knowledge products and activities that emerge from our mode of engaged scholarship.

Finally, the experiences of women struggling for sexual and reproductive rights in the Philippines speak to another theme of this volume: the increasing interconnectedness of nations as evidenced in the many efforts towards various forms of regional and transnational integration, and the threats to and possibilities for global solidarity and well-being that this brings. One such threat from the increasing interconnectedness of economic systems involves the current global economic crises that continue to haunt Europe and the United States and which affect large numbers of the world's population. Religious fundamentalisms and other undemocratic political projects are fed by the insecurity and alienation brought about by globalisation, with resultant struggles around the national, tribal and religious identities that often affect women's rights (Estrada-Claudio 2010: 38). Such struggles again take particular national forms of expression, which nonetheless have global implications.

Like feminists in other parts of the world, those of us who have struggled for sexual and reproductive rights have been accused repeatedly of trying to impose Western interests and values. ${ }^{19}$ It is not within the purview of this chapter to discuss the disjunctures and conjunctures within the various feminisms. A simple but cogent summary of these nuances, however, can be found in Rabar (2013):

Many people argue that feminism is a Western ideology and therefore has no place in the Middle Eastern societies. The term feminist and feminism might have been coined in the West, but its goals are worldwide because patriarchy has no language or colour, and female subjugation is a global issue, not just a Western

18 Several professor emeriti, university professors and full professors of various universities made public statements in support of the RH Bill, and contributed time to the campaign, including writing informative and persuasive articles for communities and the general public. This fact must be stated because those of us who question current criteria for what is 'academic' are either accused of not being able to live up to these standards or patronised with advice as to how we can get ourselves published in peer-reviewed and reputable scientific and preferably international journals.

19 I direct readers' attention to another Varsitarian article in order to reinforce my contention above that the UST served as a bastion of support for the anti-RH forces (Varsitarian 2013). 
one. If people were to follow this logic, it is akin to saying that Islam belongs to Arab societies because it was created in the Arabian Peninsula. There are dozens of feminist organisations in the Middle East that aim to eradicate inequality within the society. They are not Western organisations but have been initiated by local people with an interest in protecting and promoting the rights of women.

Feminism in the Middle East has its own narratives and differs from the Western feminism in many regards. It is a category in its own right. There are differences between Black feminism, European feminism, Arab feminism and many other types of feminism. It is a unique movement because it encompasses different cultures, and countries, but has only one goal to create egalitarian societies where women are given equal rights and opportunities.

I have often countered the argument that feminists are captured by Western individualistic modes of sexual expression by noting that current conceptions of female sexuality are also foreign impositions. As Melencio (2009) notes, Catholicism and the peculiar sexual mores now touted by conservatives as Philippine tradition were actually imposed on the Philippines by the Spanish colonists.

What these debates highlight is that approaches such as what has been called 'area studies' (Jayasuriya 2012) can often limit the understanding of certain issues within a particular nation. Philippine feminists working for the RH Bill have had to balance the contingencies of various identity positions and struggles. They have managed to balance the demands of Philippine citizenship, the problematics of racism and elitism within feminist movements, and the necessity for cross-border solidarity movements. Like feminists in other locales, they live the contradictions of a desire to preserve the uniqueness of their national culture and identity without sacrificing an allegiance to a human rights regime that sees rights as inalienable and indivisible. I would contend that these strategies, which have been forged within social movements, can be a paradigm for just and equitable forms of integration and globalisation.

First, social science research looking at cross-border issues needs to take into consideration the increasing porousness of national/political barriers as the world becomes even more intertwined and globalised. This calls for a reconsideration of traditional approaches that assume greater homogeneity within nations and a clearer demarcation of national boundaries and processes. Our experiences, therefore, support Jayasuriya's (2012) proposal for a problem-oriented approach in social science research. Such a problem-oriented approach best captures the transnational nature of the significant social struggles that we are undertaking.

Second, despite the increasing interpenetration of national cultures, we must acknowledge the diversity that local contexts bring. For example, let me point out that in the context of our struggle to pass the $\mathrm{RH}$ Bill, Philippine 
academia continues to refresh a very long tradition of academic engagement in national political concerns. Such an engagement works in two ways. On the one hand, our engagement is an attempt to use our expertise in service of our people's desires for social justice and human rights. On the other hand, this engagement deepens our scholarship and directs its parameters. In other words, the Philippine academic tradition that I have discussed here is influenced by its location historically in a postcolonial nation that has remained in a position peripheral to industrial and post-industrial development. In the highly politicised arena of what is considered a 'world-class' institution of higher learning, this particular tradition demands a set of criteria for determining the quality of scholarship different from those that are currently accepted as global criteria. Differing traditions such as these need to be valued if there is a future for regional integration that will benefit the peoples of Asia.

Third, as the White Paper on Australia in the Asian Century (Commonwealth of Australia 2012: 3) notes, 'Australia's future is irrevocably tied to the stability and sustainable security of our diverse region'. As citizens and particularly as academics, we need to take a very nuanced and, I would add, a politically informed view of 'diversity'. The engaged scholarship that we are called on to undertake in the Philippines may be very different from the intellectual engagements of academia in other countries in the region. Certain principles such as human rights and freedoms, however, remain matters of cross-cutting concern for academia as well as the larger society.

Regional integration needs to balance the need to preserve cultural diversity and richness with the goals of economic equity and people-to-people solidarity within and across nations. As I have discussed in this essay, some of the practices that can guide this effort arise from social movement actors who lead multiple identities as academics and national citizens who are nonetheless conscious of the demands of being global citizens in an increasingly integrated world.

\section{References}

Abinales, Patricio N. and Amoroso, Donna J. 2005. State and Society in the Philippines. Lanham, MD: Rowman \& Littlefield.

Alave, Kristine L. 2012. Catholic bishop goes after Ateneo professors for heresy. Philippine Daily Inquirer 21 August. URL: newsinfo.inquirer. net/254188/catholic-church-wants-pro-rh-bill-ateneo-professors-sacked. Consulted 4 April 2015.

Alliance for the Family Foundation Philippines. n.d. alfi.org.ph/links/. Consulted 28 September 2013. 
An Act Providing for a Comprehensive Policy on Responsible Parenthood, Reproductive Health, and Population and Development, and for Other Purposes. House Bill 4244. URL: www.congress.gov.ph/download/basic_15/HB04244. pdf. Consulted 22 July 2013.

An Act Providing for a National Policy on Reproductive Health and Population and Development. SB 2865. URL: www.senate.gov.ph/lisdata/115029777!. pdf. Consulted 22 July 2013.

An Act Providing for a National Policy on Responsible Parenthood and Reproductive Health. RA 10354. URL: www.gov.ph/2012/12/21/republic-act-no-10354/. Consulted 22 July 2013.

An Act to Strengthen The University of the Philippines as the National University. Republic Act No. 9500. 2008. URL: wwwl.up.edu.ph/wp-content/ uploads/2013/04/RA_9500.pdf. Consulted 24 August 2013.

BBC. 2011. MPs in Catholic Malta pass historic law on divorce. BBC 25 July. URL: www.bbc.co.uk/news/world-europe-14285882. Consulted 11 August 2013.

Bernal, Buena. 2014. SC declares RH law constitutional. Rappler 8 April. URL: www.rappler.com/nation/54946-supreme-court-rh-law-constitutional. Consulted 5 December 2014.

CBCP [Catholic Bishops' Conference in the Philippines]. 2000. That they may have life and have it abundantly. Manila: CBCP. URL: cbcponline.net/v2/?p=449. Consulted 11 August 2013.

Colliton, William, F., jr. n.d. Birth control pill: Abortifacient and contraceptive. URL: www.aaplog.org/position-and-papers/oral-contraceptive-controversy/ birth-control-pill-abortifacient-and-contraceptive/. Consulted 29 September 2013.

Commission on Community Engaged Scholarship in the Health Professions. 2005. Linking scholarship and communities: Report of the Commission on Community Engaged Scholarship in the Health Profession. Seattle: Community Partnerships for Health.

Cochrane, Donald. 2004. The Vatican, sexuality, and homosexuality. California: University of Saskatchewan. URL: www.usask.ca/education/people/ cochraned/the_vatican.pdf. Consulted 11 August 2013.

Commonwealth of Australia. 2012. Australia in the Asian Century. White Paper. Canberra: Commonwealth of Australia. 
Danguilan, Marileen J. 1997. Women in brackets: A chronicle of Vatican power and control. Manila: Philippine Center for Investigative Journalism.

de Dios, Emmanuel S. 2008. Secular morality and the university. Discussion Paper No. 2008, 05. Manila: School of Economics, University of the Philippines.

Demeterio-Melgar, Junice Lirza, Pacete, Jocelyn C., Aguiling-Pangalangan, Elizabeth, Lu, Anna Victoria M. and Sabundayo, Maria Lourdes. 2007. Imposing misery: Manila's ten year ban on contraceptives. Pardiss Kerbai, ed. New York: Likhaan, ReproCen and Center for Reproductive Rights. URL: $\quad$ www2.ohchr.org/english/bodies/cescr/docs/info-ngos/CRR_ ReportPhilippines.pdf. Consulted 16 November 2012.

Department of Health-National Epidemiology Center. 2012. Philippine HIV and AIDS registry. Manila: Department of Health-National Epidemiology Center. URL: aidsdatahub.org/dmdocuments/NEC_HIV_July-AIDSreg2012.pdf. Consulted 12 November 2012.

DLSU [De La Salle University]. n.d. About DLSU. Manila: DLSU. URL: www. dlsu.edu.ph/inside/. Consulted 24 November 2013.

Estrada-Claudio, Sylvia. 2010. Sanctifying moral tyranny: Religious fundamentalisms and the political disempowerment of women. In Claudia Derichs and Andrea Fleschenberg, eds. Religious fundamentalisms and their gendered impacts in Asia. Berlin: Friedrich-Ebert, Stiftung.

Filipino Freethinkers. 2012. Excommunicate me. 26 November. URL: filipinofreethinkers.org/excommunicateme/. Consulted 23 September 2013.

Freedman, Lynn. 1996. The challenge of fundamentalisms. Reproductive Health Matters (8): 55-69.

GMA News Online. 2008. CBCP head scores 'DEATH' bills in congress. GMA News Online. URL: www.gmanetwork.com/news/story/106120/news/nation/ cbcp-head-scores-death-bills-in-congress. Consulted 12 November 2012.

Guttmacher Institute. 2009. Meeting women's contraceptive needs in the Philippines. New York: Guttmacher Institute. URL: www.guttmacher.org/ pubs/2009/04/15/IB_MWCNP.pdf. Consulted 21 August 2013.

Hagopian, Frances. 2009. Introduction. In Frances Hagopian, ed. Religious pluralism, democracy, and the Catholic church in Latin America. Notre Dame, IN: University of Notre Dame Press.

Human Life International. n.d. Web page. URL: www.hli.org/news/1095-ligayaacosta. Consulted 29 September 2013. 
Individual Faculty of the Ateneo de Manila University. 2008. Catholics can support the RH bill in good conscience. abs-cbnNEWS.com 23 October. URL: $\quad$ www.abs-cbnnews.com/views-and-analysis/10/22/08/catholics-cansupport-rh-bill-good-conscience-0. Consulted 17 August 2013.

Jayasuriya, Kanishka. 2012. Building Australian research capacity on Asia: A new problem-oriented strategy. Indo-Pacific Research Center Policy Brief No. 1. Adelaide: University of Adelaide.

Jiminez David, Rina. 2013. Cheers for RH law at 'Women Deliver'. Philippine Daily Inquirer 30 May. URL: opinion.inquirer.net/53639/cheers-for-rh-lawat-women-deliver. Consulted 22 July 2013.

Llaguno, Frankie. 2010. New DOH chief backs reproductive health bill. $A B S$ CBN News.Com 26 January. URL: www.abs-cbnnews.com/lifestyle/01/26/10/ new-doh-chief-backs-reproductive-health-bill. Consulted 23 August 2013.

Likhaan. n.d. Likhaan Center for Women's Health Inc. URL: www.likhaan.org/. Consulted 16 November 2012.

Melencio, G. 2009. Historical markers on Filipino women's sexuality during Spanish colonial times. URL: philippinehistory.ph/historical-markers-onfilipino-women \%E2\% 80\%99s-sexuality-during-spanish-colonial-times/. Consulted 16 November 2012.

National Historical Commission of the Philippines. n.d. The life and writings of Dr Jose Rizal. Manila: National Historical Commission of the Philippines. URL: joserizal.nhcp.gov.ph/Biography/man_and_martyr/chapter17.htm. Consulted 7 August 2013.

Pro-Life Philippines. 2015. History. Manila: Pro-Life Philippines. URL: www. prolife.org.ph/?page_id=74. Consulted 15 March 2015.

Rabar, Ruwayda Mustafah. 2013. Five myths about feminism in the Middle East. Arabian Gazette 1 February. URL: www.arabiangazette.com/5-myths-aboutfeminism-in-middle-east/. Consulted 10 October 2013.

Rappler. 2012. UST disowns Varsitarian's stance vs 'lemons, cowards'. Rappler 9 October. URL: www.rappler.com/nation/13905-ust-disowns-varsitarian-sstance-vs-lemons,-cowards. Consulted 20 August 2013.

Republic of the Philippines, Supreme Court En Banc Notice. 19 March 2013. URL: $\quad$ sc.judiciary.gov.ph/jurisprudence/resolutions/2013/03/204819.pdf. Consulted 22 July 2013. 
Rufo, Aries C. 2013. Altar of secrets. Manila: Journalism for Nation Building Foundation.

Salaverria, Leila B. 2012. Arroyo charged with plunder for misuse of PCSO funds. Philippine Daily Inquirer 17 July. URL: newsinfo.inquirer.net/229539/ arroyo-slapped-with-plunder-case. Consulted 5 December 2014.

Social Weather Stations. 2011. Second quarter 2011 social weather survey: $82 \%$ say family planning method is a personal choice; $73 \%$ want information on legal methods available from government. 11 August. URL: www.sws.org.ph/ pr20110811.htm. Consulted 15 March 2015.

Social Weather Stations. 2014. SWS confirms survey on RH Law for The Forum for Family Planning and Development. 7 April. URL: www.sws.org.ph/ pr20140407_SWS\%20Confirms\%20Survey\%20on\%20RH\%20Law\% 20 for $\% 20$ T he $\% 20$ Forum \%20(media \%20release).pdf. Consulted 4 April 2015.

Suller, Erika. 2012. UST student paper calls Ateneo, La Salle lemons and cowards. Philippine Daily Inquirer 9 October. URL: newsinfo.inquirer. net/285548/ust-student-paper-calls-ateneo-la-salle-lemons-and-cowards. Consulted 5 December 2014.

UN [United Nations]. 2006. In-depth study on all forms of violence against women. Report of the Secretary-General. A/61/122/Add.1 New York: UN. URL: daccess-dds-ny.un.org/doc/UNDOC/GEN/N06/419/74/PDF/N0641974. pdf?OpenElement. Consulted 15 August 2013.

UNHRC [United Nations Human Rights Council]. 2012. Concluding observations on the fourth periodic report of the Philippines, adopted by the Committee at its 106th session, 15 October to 2 November. Advanced and unedited copy. New York: UNHRC. URL: reproductiverights.org/sites/crr.civicactions.net/ files/documents/crr_Philippines_Concluding_Observations.pdf. Consulted 10 August 2013.

UST [University of Santo Tomas]. n.d. History. Manila: UST. URL: www.ust. edu.ph/about-us/history/. Consulted 15 March 2015.

Varsitarian. 2012. Of lemons and cowards. 30 September. URL: www.varsitarian. net/editorial_opinion/editorial/20120930/rh_bill_ateneo_and_la_salle_of_ lemons_and_cowards. Consulted 12 October 2012.

Varsitarian. 2013. RH exposed as an imperialist tool. 8 April. URL: www. varsitarian.net/news/20130408/rh_exposed_as_us_imperialist_tool. Consulted 5 December 2014. 
Wezel, Christian. 2006. A human development view on value change trends 1981 to 2006. PowerPoint Presentation. World Values Survey. URL: www.worldvaluessurvey.org. Consulted 4 December 2014.

Whitaker, Brian. 2005. Fundamental union. When it comes to defining family values, conservative Christians and Muslims are united against liberal secularists. The Guardian, 25 January. 
This text is taken from The Social Sciences in the Asian Century, edited by Carol Johnson, Vera Mackie and Tessa Morris-Suzuki, published 2015 by ANU Press, The Australian National University, Canberra, Australia. 